\title{
The Quality of China's Household Income Surveys
}

\section{Chris Bramall}

Much recent research on the Chinese economy has centred on analysing changes in the personal distribution of income in China since 1978. The purpose of this research has been both to delineate the trend in income inequality over time, and to "decompose" this trend into its component parts. ${ }^{1}$ The central conclusions to emerge are that income inequality has increased sharply during the transition era, and that spatial factors particularly a rise in inter-provincial income differentials and an increase in the urban-rural gap - have played a key role in the process. The policy conclusion which has usually been drawn is that the Chinese state needs to dismantle the remaining restrictions on labour mobility because these have served to prevent the fruits of growth from "trickling down" from urban areas and the eastern provinces to the Chinese hinterland. It is argued that such a policy would raise rural wages and reduce urban wages, thus reducing the urban-rural income gap. The removal of obstacles to labour migration would also serve to reduce the income gap between the coastal provinces and those of the interior.

The purpose of this report is to scrutinise the quality of the survey data on which these conclusions are based. It will be argued that, even after

1. Some of the most important recent studies include Azizur Rahman Khan, Keith Griffin, Carl Riskin and Zhao Renwei, "Household income and its distribution in China," The China Quarterly. No. 132 (December 1992); Keith Griffin and Zhao Renwei (eds.), The Distribution of Income in China (London: Macmillan, 1993); Scott Rozelle, "Stagnation without equity," The China Journal, No. 35 (January 1996); World Bank, Sharing Rising Incomes (Washington D.C.: World Bank, 1997); Li Shi, Zhao Renwei and Zhang Ping, "Zhongguo jingji zhuanxing yu shouru fenpei biandong" ("China's economic transition and changes in the income distribution"), Jingji yanjiu (Economic Research), No. 4 (April 1998); Azizur Rahman Khan and Carl Riskin, "Income and inequality in China," The China Quarterly, No. 154 (June 1998); Lin Yifu, Cai Fang and Li Zhou, "Zhongguo jingji zhuanxing shiqi de diqu chaju fenxi" ("An analysis of regional inequalities during China's transition"), Jingji yanjiu (Economic Research), No. 6 (June 1998): Hy Van Luong and Jonathan Unger, "Wealth, power and poverty in the transition to market economies," The China Journal, No. 40 (July 1998); Tsui Kai-yuen, "Factor decomposition of Chinese rural income inequality," Journal of Comparative Economics, Vol. 26, No. 3 (September 1998); Li Shi and Zhao Renwei, "Zhongguo jumin shouru fenpei zaiyanjiu" ("The Chinese income distribution revisited"), Jingji yanjiu, No. 4 (April 1999); Dennis T. Yang, "Urban-biased policies and rising income inequality in China," American Economic Review, Papers and Proceedings (May 1999); Li Shi, Zhao Renwei and Carl Riskin (eds.), Zhongguo jumin shouru fenpei zaiyanjiu (The Chinese Income Distribution Revisited) (Beijing: Zhongguo caizheng jingji chubanshe, 1999). Important early studies include E. B. Vermeer, "Income differentials in rural China." The China Quarterly, No. 89 (1982); Lee Travers, "Bias in Chinese economic statistics," The China Quarterly, No. 91 (1982) and Irma Adelman and David Sunding, "Economic policy and income distribution in China," Journal of Comparative Economics, Vol. 11, No. 3 (September 1987). This list takes no account of the large number of studies which have looked at the distribution of per capita output using data on gross output value, net material product and GDP. 
the adjustments to the State Statistical Bureau survey data made by (inter alia) Khan, Zhao and Riskin, the data on China's personal income distribution still provide too fragile a basis for firm policy conclusions. There is no question that income inequality has increased dramatically since 1978, but both the extent of the increase and its underlying causes are still very far from clear.

\section{Changes in Chinese Income Distribution after 1978}

The last State Statistical Bureau (SSB) survey of rural incomes prior to the Cultural Revolution occurred in 1965 and covered 11,683 households. ${ }^{2}$ These households were required to keep a record of their income and expenditure (and received a small payment in return). The survey resumed in 1977, when it covered 3,646 households; the figure had risen to 18,529 households by 1981 . In 1985 , the sample was significantly re-organized. It was expanded to cover 66,642 households drawn from 846 counties, including some located in Tibet. The methodology was also altered to provide more systematic measurement of income and expenditure. Further significant changes occurred in 1990. In order to avoid the problem of sample ageing, provision was made for the annual replacement of a proportion of the households; by the late 1990s, this ensured that the entire sample was replaced every four years. In addition, the representation of the three large municipalities was increased as a proportion of the total. Nevertheless, the overall size of the sample changed little after the mid-1980s: for example, the 1998 rural survey included 68,300 households. $^{3}$

Urban income surveys also ceased during the Cultural Revolution; the last survey of which anything is known is for 1964, which sampled 3,537 households. Survey work began again in 1977-78, when a panel of 88,282 households was established, but it was not until 1980 that the sample survey was fully restored, with 7,962 households covered. Attempts were made to ensure that these were drawn from county towns as well as the great metropolitan centres and, as in rural China, selected households were required to keep a record of their income and expenditure. After 1985, when 24,338 households were included, the size of the urban survey steadily rose. In 1989, it covered 27,795 households living in cities and a further 7,440 in county towns, a total of 35,235 . $^{4}$ These

2. The SSB (Guojia tongjiju) has recently taken to calling itself the National Bureau of Statistics; SSB is used throughout this article for consistency. The evolution of the SSB surveys is traced in Yoshiro Matsuda, "Survey systems and sampling designs of Chinese household surveys, 1952-1987," The Developing Economies, Vol. XXVIII, No. 3 (September 1990), and Yue Wei, Dangdai Zhongguo de tongji shiye (China Today: Statistics) (Beijing: Zhongguo shehui kexue chubanshe, 1990), pp. 543-554 and 555-574.

3. SSB, Zhongguo tongji nianjian 1999 (Chinese Statistical Yearbook) (Beijing: Zhongguo tongji chubanshe, 1999), p. 337. All Chinese Statistical Yearbooks are hereafter abbreviated as ZGTJNJ.

4. SSB, 1989 Zhongguo chengzhen jumin jiating shouzhi diaocha ziliao (The Incomes and Expenditure of China's Urban Households in 1989) (Beijing: Zhongguo tongji chubanshe, 1990), pp. 67 and 73. 
figures again changed little during the 1990s: for example, the 1998 survey covered 39,080 households.

The degree of inequality of personal income identified by these surveys is shown in Table 1. There are three main points to note. First, the gini coefficients in the late 1970s were very low by international standards. ${ }^{5}$ This was especially true of the coefficients for the rural and urban sectors considered separately. The overall gini coefficient was much higher than either sectoral figure because of the substantial urban-rural income gap; the main problem, as is well known, was the high level of subsidies paid to urban residents. Nevertheless, the overall gini coefficient at the beginning of the transition era was still modest by comparison with most developing countries, and especially so when compared with the Latin American norm of 0.5 or more. A second feature of Table 1 is that income inequality rose substantially after 1978 in both urban areas and in the countryside. In the early years of transition, the pace of increase was most rapid in the rural sector (although it may have dipped slightly in $1982-83$ at the height of decollectivization when land and other assets were distributed on a per capita basis). For the period between 1978 and 1987, the rural gini increased by 8 percentage points whereas the urban gini rose by only 4 points. By contrast, it was rising urban inequality which dominated after 1987; rural inequality continued to rise, but not by as much as urban inequality. ${ }^{6}$

Thirdly, the overall pace of inequality increase was much faster than had been envisaged by the Party at the beginning of the transition period. In 1979, Deng Xiaoping announced that the aim of China's "four modernizations" was to achieve a "comfortable" (xiaokang) standard of living by 2000, a goal re-affirmed by successive CCP Congresses. ${ }^{7}$ The standard of living was subsequently defined by the SSB in 1992 to include 12 elements, ranging from the middle school enrolment rate to income inequality. ${ }^{8}$ The xiaokang target for the latter was a gini coefficient of 0.30 to 0.35 . Separate targets were set for rural and urban areas: 0.30 to 0.40 for the countryside, and 0.26 to 0.30 for urban China. ${ }^{9}$ The underlying logic was that a more equal distribution than the xiaokang

5. The gini coefficient is the most widely-used measure of income dispersion in the literature. It ranges from 0 (no inequality) to 1 .

6. Using ordinary least squares to estimate growth rates for the transition era, the urban gini rose by $4.3 \%$ per year (1978-96), the rural gini by $2.5 \%$ (1978-97) and the overall gini by $2.3 \%(1980-96)$.

7. According to Deng: "The minimum target of our four modernizations is to achieve a comparatively comfortable standard of living by the end of the century. I first mentioned this with former prime minister Masayoshi Ohira of Japan during his visit here in December 1979" (Deng Xiaoping, "Build socialism with Chinese characteristics," in Central Committee, Major Documents of the People's Republic of China, December 1978-November 1989 (Beijing: Foreign Languages Press, 1991), p. 3). For the re-affirmation of the target, see John Wong, "Xiao-Kang: Deng Xiaoping's socio-economic development target for China," in Wang Gungwu and John Wong (eds.), China's Political Economy (Singapore: Singapore University Press, 1998).

8. SSB, Zhongguo xiaokang biaozhun (China's Xiaokang Standard) (Beijing: Zhongguo tangji chubanshe, 1992).

9. Yin Shijie, Zhongguo xiaokang shuiping yanjiu (Research on China's Xiaokang Target) (Changsha: Hunan chubanshe, 1994), pp. 48-55. 
Table 1: State Statistical Bureau Estimates of Chinese Income Inequality (gini coefficients)

\begin{tabular}{lccc}
\hline & Rural & Urban & Overall \\
\hline 1978 & 0.21 & 0.16 & $\mathrm{n} / \mathrm{a}$ \\
1979 & $\mathrm{n} / \mathrm{a}$ & $\mathrm{n} / \mathrm{a}$ & $\mathrm{n} / \mathrm{a}$ \\
1980 & 0.24 & 0.16 & 0.28 \\
1981 & 0.24 & 0.16 & $\mathrm{n} / \mathrm{a}$ \\
1982 & 0.23 & 0.15 & $\mathrm{n} / \mathrm{a}$ \\
1983 & 0.25 & 0.15 & $\mathrm{n} / \mathrm{a}$ \\
1984 & 0.26 & 0.16 & $\mathrm{n} / \mathrm{a}$ \\
1985 & 0.26 & 0.19 & $\mathrm{n} / \mathrm{a}$ \\
1986 & 0.29 & 0.19 & $\mathrm{n} / \mathrm{a}$ \\
1987 & 0.29 & 0.20 & $\mathrm{n} / \mathrm{a}$ \\
1988 & 0.30 & 0.23 & $\mathrm{n} / \mathrm{a}$ \\
1989 & 0.30 & 0.23 & $\mathrm{n} / \mathrm{a}$ \\
1990 & 0.31 & 0.23 & 0.36 \\
1991 & 0.31 & 0.24 & $\mathrm{n} / \mathrm{a}$ \\
1992 & 0.31 & 0.25 & $\mathrm{n} / \mathrm{a}$ \\
1993 & 0.32 & 0.27 & 0.38 \\
1994 & 0.33 & 0.30 & $\mathrm{n} / \mathrm{a}$ \\
1995 & 0.34 & 0.28 & 0.41 \\
1996 & $\mathrm{n} / \mathrm{a}$ & 0.28 & 0.39 \\
1997 & 0.33 & $\mathrm{n} / \mathrm{a}$ & $\mathrm{n} / \mathrm{a}$ \\
1998 & 0.33 & $\mathrm{n} / \mathrm{a}$ & $\mathrm{n} / \mathrm{a}$ \\
1999 & 0.35 & $\mathrm{n} / \mathrm{a}$ & $\mathrm{n} / \mathrm{a}$ \\
\hline
\end{tabular}

Sources:

Rural gini coefficients: 1978: Wang Chunzheng, Woguo jumin shouru fenpei wenti (The Issue of Income Distribution in China) (Beijing: Zhongguo jihua chubanshe, 1995), p. 90; 1980-91: Zhang Ping, "Zhongguo nongcun jumin quyujian shouru bupingdeng yu feinongjiuye" ("Regional income inequality and non-agricultural employment in rural China"), Jingji yanjiu (Economic Research), No. 8 (August 1998), p. 60; 1992: Ma Hong and Sun Shangqing, Zhongguo jingji xingshi yu zhanwang 1994-95 (China's Economic Situation and Prospects) (Beijing: Zhongguo fazhan chubanshe, 1995), p. 259; 1993 and 1994: SSB, Zhongguo nongcun tongji nianjian 1995 (Chinese Rural Statistical Yearbook) (Beijing: Zhongguo tongji chubanshe, 1996), p. 4; 1995: Zhang Ping, "Regional income inequality," p. 60. 1997 and 1998: by calculation from SSB, Zhongguo tongji nianjian 1999 (Chinese Statistical Yearbook) (Beijing: Zhongguo tongji chubanshe, 1999), p. 337; 1999: by calculation from SSB at http://www.stats.gov.cn.

Urban gini coefficients: 1978-96: Wang Mengkui and Lu Zhongyuan, Chengzhen jumin shouru chaju yanjiu (Research on Urban Income Differentials) (Beijing: Zhongguo yanshi chubanshe, 1997), p. 34.

Overall gini coefficients: 1980 and 1990: SSB, Zhongguo xiaokang biaozhun (China's Xiaokang Standard) (Beijing: Zhongguo tongji chubanshe, 1992), p. 17, 1993, 1995 and 1996: Wang and Lu, Research, p. 186. 
target would be excessively egalitarian (and would therefore provide inadequate work incentives), and that greater inequality would be incompatible with the Marxist idea of "distribution according to work done" (and perhaps produce social tensions). ${ }^{10}$ By the late $1990 \mathrm{~s}$, the official data in Table 1 suggest that China had successfully achieved its xiaokang targets for the individual sectors; the urban gini had slipped to the upper limit of its range in 1994 but it was back within it by 1996. However, the overall gini - even though it had increased much less quickly than either sectoral coefficient - was well above its target, standing at around 0.40 as compared to the expected range of 0.30 to 0.35 . These results together imply that the urban-rural gap was not reduced as rapidly as hoped when the xiaokang inequality targets were set.

\section{The Limitations of the Early State Statistical Bureau Surveys}

The inferences drawn in the previous paragraphs are based upon the data collected in the annual SSB surveys. However, the quality of these surveys during the early 1980s was exceptionally poor, and glaring weaknesses remained even in the surveys of the mid and late 1990s.

One persistent problem has been geographical coverage. The 1978 rural survey covered only 20 provinces, and Qinghai and Tibet were excluded until 1981 and 1984 respectively: the apparent increase in the rural gini between 1978 and 1980 may simply reflect the inclusion of "missing" provinces. ${ }^{11}$ The urban sample was similarly deficient. Even in 1989, when 35,235 urban households were surveyed, only 7,440 (21 per cent) were drawn from county towns (zhen). ${ }^{12}$ Yet the 1990 Population Census recorded a total urban population of 296.5 million, of whom 85.3 million lived in zhen (29 per cent). ${ }^{13}$ This suggests that the population of China's county towns was under-represented, a significant weakness given its lower per capita income (1,106 yuan per annum as against 1,367 yuan); this weakness had not been remedied even in the late 1990s. The geographical coverage of the 1989 urban sample was also odd in that only 500 households resident in Shanghai were included, whereas there were 1,000 Beijing households, 1,000 from Tianjin and (more remarkably) 830 from Gansu. ${ }^{14}$ Yet Shanghai's urban population (zhen and shi combined) was estimated at almost 9 million in the 1990 Census, comfortably exceeding the urban populations of Beijing (8 million), Tianjin (6 mil-

10. The argument was re-stated by Zhao Ziyang in 1987 in his speech "Advance along the road of socialism with Chinese characteristics," in Central Committee, Major Documents, p. 668 . He concluded that the income distribution at the time was still too equal: "The practice of allowing everyone to 'eat from the same big pot,' egalitarianism and jealousy of other people's higher incomes still constitute the main tendency in income distribution at present."

11. The provinces excluded in 1978, but included in 1980, were Guangxi, Jiangxi, Shaanxi, Shanxi, Xinjiang and Zhejiang. Of these, only Zhejiang and Xinjiang (barely) registered per capita income levels above the average. See SSB, ZGTJNJ 1991, p. 296.

12. SSB, 1989 Incomes and Expenditure, pp. 73 and 79.

13. Population Office, Major Figures of the Fourth National Population Census of China (Beijing: Zhongguo tongji chubanshe, 1991), p. 32.

14. These data include both households resident in cities, and households resident in county towns. From SSB, 1989 Incomes and Expenditure, p. 79. 
lion) and Gansu (less than 5 million). This treatment of Gansu is reflective of a more general tendency to over-represent China's poorer provinces in the household surveys for political reasons, and the net effect on the income distribution is difficult to determine. ${ }^{15}$ Weighting procedures can offset the impact of a small sample; one could give greater weight to each Shanghai household in the overall sample, or choose households from the upper end of the Shanghai distribution. But there is no evidence that this was done, and it is plain that representing provinces in the sample in proportion to their populations would be an altogether more simple procedure.

A second problem with the SSB surveys has been occupational coverage. The rural surveys of the 1980s sampled only peasant households, and thereby excluded rural households specializing in non-agricultural production or dependent upon wage income earned outside agriculture. ${ }^{16}$ This was not much of a problem in the early 1980s when there were few rural households wholly reliant upon the non-agricultural sector for their income. Nevertheless, as the diversification of the rural economy proceeded, so the rural sample became less representative. The effect was probably to understate inequality: many of the excluded households received incomes which were either well above or well below the average. A similar problem affected the urban surveys of the early 1980s. These were restricted to staff and worker households, thereby excluding self-employed and retired households. As with the rural survey, the effect was probably to understate income inequality.

A third prominent weakness of the SSB surveys has been the use of a narrow definition of income. ${ }^{17}$ Neither urban nor rural surveys attempted to estimate the rental value of housing, even though most rural households owned their own house and urban households paid rent at below the implicit market rate. In addition, the value of subsidies paid in cash and in kind to urban households was greatly under-estimated, a particular problem for the urban sector where subsidies accounted for over 80 per cent of wages throughout the 1980s and 1990s. ${ }^{18}$ These subsidies included cheap grain and vegetable oil, health, retirement, death, maternity and disability benefits, childcare benefits, low rent housing, a commuting subsidy, subsidized coal, and subsidized visits to distant relatives. The income concept used in the rural surveys was problematic in another respect: the valuation of self-consumed farm products at contract purchas-

15. The extent of over-representation was reduced after 1990, but it was not eliminated. For example, there were some 50\% more Jiangsu than Guizhou households in the 1996 rural sample even though Jiangsu's rural population (nongye renkou) was about $70 \%$ larger. From Guizhou tongjiju (Guizhou Statistical Bureau), Guizhou tongji nianjian 1997 (Guizhou Statistical Yearbook). (Beijing: Zhongguo tongji chubanshe, 1997), p. 121 and Jiangsu tongjiju (Jiangsu Statistical Bureau), Jiangsu tongji nianjian 1997 (Jiangsu Statistical Yearbook), (Beijing: Zhongguo tongji chubanshe, 1997), p. 91.

16. Matsuda, "Survey systems," p. 342.

17. Griffin and Zhao, Distribution of Income, pp. 29-34.

18. Nicholas Lardy, "Consumption and living standards in China, 1978-1983," The China Quarterly, No. 100 (December 1984), pp. 853-56. Ma Hong, Modern China's Economy and Management (Beijing: Foreign Languages Press, 1990), pp. 453-59. See also Table 3, below. 
ing prices. In the case of grain, the contract price was below the market price and therefore the incomes of poor peasants was understated - thus exaggerating the extent of inequality. ${ }^{19}$ But in some cases, such as milk, the contract price was arguably too high and therefore the income of herdsmen was exaggerated in the surveys. The net effect cannot be judged. The "true" price of self-consumed milk for the purpose of determining the income of herdsmen ought to be the price herdsmen would have been willing to pay given a "free" choice. However, there is self-evidently no way of establishing that in unambiguous fashion. But the probable understatement in the surveys of the price of grain, the most important self-consumed food product, had the effect of increasing income inequality because it undervalued the incomes of (predominantly poor) households who marketed only a small proportion of their production. ${ }^{20}$

\section{New Estimates of Income Inequality}

These flaws in the SSB surveys were well-known by the mid-1980s, and attempts to improve them proceeded along two lines. First, the SSB itself did much to improve the sampling. The occupational coverage of the urban sample was expanded in 1985 to include the self-employed and retired households; the name of the survey was even altered - from zhigong jiating (staff and worker households) to chengzhen jumin jiating (urban resident households) - to signal this change. A comparison of the 1984 and 1985 data shows that the effect of expanded occupational coverage was to increase urban inequality. For example, 5.1 per cent of households received less than 25 yuan per capita per month in 1985 compared to only 1.7 per cent in 1984 , a change that can be explained only in terms of an alteration in sampling design. ${ }^{21}$

The coverage of the rural sample also expanded in the mid-1980s. By 1984 , every province was included, and in the following year the size of the sample was raised from 31,375 to 66,642 households. In 1994, it was finally acknowledged that there were too many rural households entirely detached from agriculture to justify their exclusion any longer: the nongmin jiating (peasant household) survey thus became the survey of rural resident households (nongcun jumin jiating).

These changes have undoubtedly improved the quality of the household income surveys, and have persuaded some scholars that SSB gini coefficients for the late 1980 s and 1990 s can be trusted. ${ }^{22}$ However, there

19. See, for example, World Bank, China: Strategies for Reducing Poverty in the 1990s (Washington D.C.: World Bank, 1992), pp. 22-24.

20. An additional ongoing problem with the sampling procedure is that no provision is made for the impact of inflation or deflation on per capita incomes when altering the composition of the sample. I am indebted to an anonymous referee for this point.

21. SSB, ZGTJNJ 1987, p. 691.

22. For example, Yang has argued that "the Household Surveys provide appropriate (and perhaps the best) data" (Yang, "Urban-biased policies," p. 307). The SSB data have also been viewed as reliable enough for decomposition analysis designed to identify the sources of rising inequality; see Tsui, "Factor decomposition" and Yao Shujie, "Economic growth, income 
are good reasons for remaining sceptical. Several Chinese institutions have conducted surveys of their own, and come up with estimates of inequality which are substantially greater than the SSB figures. For example, a survey conducted in late 1984 and early 1985 by the Rural Policy Research Unit of the CCP and the Rural Development Research Centre of the State Council put the rural gini coefficient for 1984 at 0.40, far above the SSB figure of $0.26 .^{23}$ A decade later, a survey by the Social Survey Centre at the People's University of China put the urban gini at 0.37, again well above the SSB figure for $1994 .{ }^{24}$

In the West, meanwhile, an attempt was made in the mid-1980s to adjust the SSB estimate of inequality to incorporate the impact of urban subsidies on the urban-rural income differential. ${ }^{25}$ More recently, the World Bank has tried to revise the SSB data but, without access to the raw household data, its work has relied of necessity upon ad hoc revisions. ${ }^{26}$

The most systematic re-appraisal of the SSB data was begun by a team of Chinese and Western researchers in the late 1980s, and the results of this work began to appear in print in $1992 .{ }^{27}$ The team took a subset of the SSB data for 1988 (and later for 1995), and adjusted the income estimates to correct three perceived weaknesses. First, the imputed rental value of housing was included in income. Secondly, the range of subsidies included in income was widened. Thirdly, self-consumed farm products were re-valued at market prices. One result of these adjustments was to raise household per capita income; the Khan and Riskin figure for the average rural resident in 1988 was 564 yuan, compared to 453 yuan in the original SSB survey; the inclusion of housing rental value alone contributed 73 yuan of this difference. In the urban sector, the inclusion of a wider range of subsidies raised per capita income by no less than 20 per cent. ${ }^{28}$ The divergence between the rural SSB and the revised sample

footnote continued

inequality and poverty in China under economic reform," Journal of Development Studies, Vol. 35, No. 6 (August 1999).

23. Zhonggong zhongyang shujichu nongcun zhengce yanjiushi ziliaoshi (Rural Policy Research Office of the Secretariat of the Central Committee), Zhongguo nongcun shehui jingji dianxing diaocha (A Typical Example Survey of China's Rural Economy and Society) (Beijing: Zhongguo shehui kexue chubanshe, 1988). The details of this survey, which was biased towards higher income areas, are discussed in Chris Bramall and Marion E. Jones, "Rural income inequality in China since 1978." Journal of Peasant Studies, Vol. 21, No. 1 (October 1993).

24. Wang and Lu, Research, p. 4.

25. Adelman and Sunding, "Economic policy and income distribution."

26. The Bank adjusted urban incomes to allow for subsidies, but at the same time reduced (relative) urban income by assuming that the cost of living was $15 \%$ higher in the cities. See World Bank, Sharing, p. 17. The often-cited World Bank estimate of inequality in the early 1980s did little more than replicate the official SSB gini; the figure cited for 1981 of 0.29 (World Bank, Sharing, p. 1) for the overall gini is virtually identical to the official figure of 0.28 for 1980 (Table 1, above).

27. Khan et al., "Household income"; Griffin and Zhao, Distribution of Income; Khan and Riskin, "Income and inequality"; Li, Zhao and Zhang, "Economic transition" and Li and Zhao, "Income distribution revisited." Details of the survey questions asked in 1988 and 1995 can be found in Li, Zhao and Riskin, Income Distribution Revisited, pp. 630-697.

28. Griffin and Zhao, Distribution of Income, pp. 33 and 35. 
Table 2: Alternative Estimates of the Chinese Income Distribution, 1978-1995

\begin{tabular}{lccc}
\hline & Rural Gini & Urban Gini & Overall Gini \\
\hline 1978 & 0.22 & 0.17 & 0.32 \\
1988 & 0.34 & 0.23 & 0.38 \\
1990 & - & - & 0.41 \\
1995 & 0.42 & 0.33 & 0.45 \\
\hline
\end{tabular}

Sources:

1978: Irma Adelman and David Sunding, "Economic policy and income distribution in China," Journal of Comparative Economics, Vol. 11, No. 3 (September 1987), p. 163; 1988: Keith Griffin and Zhao Renwei (eds.), The Distribution of Income in China (London: Macmillan, 1993), p. 61; 1990: World Bank, Sharing Rising Incomes (Washington, D.C.: World Bank, 1997), p. 17; 1995: Azizur Rahman Khan and Carl Riskin, "Income and inequality in China," The China Quarterly, No. 154 (June 1998), pp. 237, 242 and 247.

was even greater in percentage terms in 1995, but was smaller for the revised urban sample, mainly because subsidies had declined in significance between 1988 and $1995 .^{29}$

The revised estimates of inequality made by Adelman and Sunding, the World Bank, and Khan and Riskin have one thing in common: they have all generated much higher gini coefficients than those computed by the SSB and given in Table 1. These new estimates are summarized in Table 2. For example, the World Bank estimate for 1990 is 5 percentage points higher than the official estimate. The story is largely the same for 1995: the Khan and Riskin estimate for that year is 4 percentage points higher than the SSB gini. This increase occurs because the sources of income omitted in the SSB surveys were much more unequally distributed than those types of income which were included.

The result of these revisions is clear. Although they confirm the upward trend apparent in the official data, they also suggest that the distribution of personal income has become more unequal than suggested by the SSB surveys; this conclusion holds at both a sectoral and national level. But just how reliable are these new figures?

\section{The Limitations of the Revised Inequality Data}

The work undertaken by Khan, Riskin and others has undoubtedly produced better estimates of income inequality. ${ }^{30}$ Nevertheless, these

29. Khan and Riskin, "Income and inequality," pp. 230-33.

30. In two respects, the revised data are actually inferior to the SSB figures. First, the revised urban sample includes an even smaller proportion of households living in county towns; for example, no county towns were included in the Liaoning urban sample. See Khan et al., "Household income," p. $1030 \mathrm{fn}$ or Griffin and Zhao, Distribution of Income, p. 333. Secondly, the number of provinces and cities covered in the sub-sample is much lower than in the SSB sample; for example, the Khan and Riskin sub-sample for 1995 excludes 
revised estimates remain seriously deficient, largely because they are still based on the data collected by the SSB. Some of the deficiencies produce a continuing under-estimation of true income inequality; these will be discussed first. But in other respects the revised inequality data may overstate true inequality, and these opposing biases are discussed at the end of this section.

To begin with those factors which lead to an under-estimation of inequality: one continuing problem is the requirement that households included in either the rural or urban survey keep a record of their income and expenditure. In practice, this has meant that illiterate households have been excluded. Although the SSB has instructed local statistical assistants to help selected illiterate households in record collection, it is likely that they have simply been omitted from the surveys. ${ }^{31}$ Given that illiteracy is still common (the 1997 One Percent Population Survey found that 10 per cent of males and 23 per cent of females aged 15 and over were illiterate) and that there is a strong correlation between illiteracy and low income, the effect is that the surveys understate inequality by excluding a significant proportion of the poor.

A second problem is the estimate of income from savings, and what this estimate implies about the coverage of the urban sample. The Khan and Riskin estimates for urban income in 1995 have property income contributing 72 yuan out of total per capita income of 5,706 yuan; rural property income was estimated to be 10 yuan. However, the aggregate savings data suggest that these estimates are too low. In 1995, total savings were 813 billion yuan. Of these, 108 billion yuan is attributable to the re-investment of interest payments. Of the remainder, 78 billion yuan were public funds deposited in the names of private individuals (gongkuan sicun). This leaves total household savings of 627 billion yuan (including 147 billion yuan saved by private entrepreneurs), implying that 89 per cent of savings are made by the household sector. ${ }^{32}$ If we apply this percentage to total accumulated savings in 1995 (2,966 billion yuan, or 2,449 yuan per capita), ${ }^{33}$ we come to a figure of 2,180 yuan per capita for the total accumulated value of personal savings. Assuming (very conservatively) an interest rate of 5 per cent, the result is a per capita income from savings (rural and urban sectors combined) of 109 yuan. This is well above even the Khan and Riskin estimate for urban savings (which was undoubtedly much higher than the combined rural-urban total).

The most plausible reason for this big discrepancy is that the SSB data used by Khan and Riskin under-sample (and perhaps even exclude) high saving private sector entrepreneurs (siying jingyingzhe). This group con-

\section{footnote continued}

Heilongjiang, Inner Mongolia, Qinghai, Ningxia, Guangxi, Fujian, Hainan, Tianjin and Shanghai for reasons of cost.

31. World Bank, Strategies, p. 154.

32. Wang and Lu, Research, p. 209. These data come from surveys jointly conducted by the SSB and the People's Bank of China.

33. SSB, ZGTJNJ 1998, p. 324. 
tributed 147 billion yuan of household savings in $1995 .{ }^{34}$ Moreover, because the high savings made by excluded entrepreneurial households reflect their high incomes, ${ }^{35}$ their inclusion in the urban survey would necessarily raise the urban gini coefficient. One estimate suggests this would raise the urban gini to about 0.31 in 1995-96 - even before the revisions made by Khan and Riskin. ${ }^{36}$ An even more drastic revision to the SSB data (this time for 1988) raises the rural gini to 0.37 and the urban gini to 0.27 ; this revision is based on an attempt to include a range of illegal income (feifa shouru). ${ }^{37}$ Of course the incomes of the rich are routinely under-reported in all countries, but it should be remembered that a "capitalist" class did not exist in China in 1978 whereas it never disappeared in most countries. The re-appearance of this class after 1978 therefore constitutes a real increase in income inequality when China is compared with other countries.

A third problem is the exclusion from the urban sample of those living in urban areas without a formal certificate of residence (hukou). It is hard to be sure about the size of the floating population because of inconsistencies in the definition of urban, and in the definition of floaters. ${ }^{38}$ Many estimates of urban floaters seem to refer only to cities; however, "urban" as defined by the urban income survey includes both county towns and cities. Using this definition, it is reasonable to argue that all the floaters live in urban areas. If true, this puts the urban floating population at around 80 million by the mid-1990s. ${ }^{39}$ Be that as it may, the omission of the floating population is significant only because its average per capita income is below the urban average. A survey of 2,900 floaters in four

34. Wang and Lu, Research, p. 209.

35 . $43 \%$ of urban savings in 1996 were held by the richest $20 \%$ of income earners, and the richest $3.5 \%$ of households held $16 \%$ of savings (ibid. p. 210).

36. Ibid. p. 196. There is much anecdotal evidence which points to a large number of very rich people living in urban China by the mid-1990s. One source put the number of households receiving more than 50,000 yuan per capita in 1998 at 5.3 million (South China Morning Post, 3 August 1998). Another estimated that there were 3 million millionaires in China in 1996 (Tong Xing, trans. in FBIS-CHI-96-069).

37. Chen Zongsheng, Jingji fazhan zhong de shouru fenpei (The Distribution of Income during Economic Development) (Shanghai: Shanghai renmin chubanshe, 1994), pp. 274-78.

38. This term, as well as floaters, is used hereafter to refer to both the "temporary population" (zhanju renkou) of urban areas (which was recorded in the population censuses of 1982 and 1990) and to those whose presence went unrecorded. Migrant (qianyi) is misleading because official Chinese sources use it to refer to those who have permanently changed their hukou.

39. A variety of estimates of the floating population are given in Dorothy Solinger, Contesting Citizenship in Urban China (Berkeley: University of California Press, 1999), pp. 19-21. Some estimates by Chinese scholars include Shen Yimin and Tong Chengzhu, Zhongguo renkou qianyi (Population Migration in China) (Beijing: Zhongguo tongji chubanshe, 1992); Li Rongshi, "Dui dangqian woguo liudong renkou de renshi he sikao" ("Reflections on China's current floating population"), Renkou yanjiu (Population Research), Vol. 20, No. 1 (January 1996); Li Rongshi, "Dui dangqian woguo nongcun renkou liudong de zai renshi" ("A reconsideration of China's current rural floating population"), Renkou yanjiu, Vol. 20, No. 6 (November 1996). For recent English-language studies, see Leila Fernandez-Stembridge and Taciana Fisac, "An overview of today's rural-urban migration flows in the People's Republic of China," in Werner Draguhn and Robert Ash, China's Economic Security (London: Curzon Press, 1999); Wang Fei-Ling, From Family to Market (Oxford: Rowman and Littlefield, 1998); and Sarah Cook and Margaret Maurer-Fazio, The Workers' State Meets the Market (London: Frank Cass, 1999). 
cities for 1995, for example, found that average floater earnings were only 80 per cent of the earnings of residents. ${ }^{40}$ This was mainly because of occupational segmentation: the floating population were principally employed in low wage jobs. This in turn partially reflected the attitude of municipal governments. In Beijing, for example, a list of 198 types of permitted work was published in February 1998: this pushed floaters into unpopular and low paid jobs such as abattoir work, burning corpses and mining. ${ }^{41}$ In the same month, "the authorities decreed that all migrants employed as postal workers, machinists, gardeners and street sweepers must be fired immediately and replaced with jobless Beijingers within 20 days" (South China Morning Post, 10 February 1998). The measure affected 120,000 floaters. Similarly, the Deputy Party Secretary of Liaoning openly encouraged unemployed workers to "grab back" the jobs held by floaters. ${ }^{42}$ The exclusion of the floating population from the urban household survey therefore produces a further under-statement of urban inequality and the need to expand the sample has been recognized by the $\mathrm{SSB}^{43}$

The factors causing an under-estimation of inequality are counter-balanced by other factors which cause the opposite bias. First, consider the impact of the exclusion of floaters from the urban survey. One effect of their exclusion is an under-estimation of the urban gini coefficient; many were employed in low wage jobs, and their disposable income was even lower because many had to pay an urban residence fee. ${ }^{44}$ However, the impact of (illegal) migration is also to depress the average urban wage and increase the average rural wage, the net effect being a narrowing of the urban-rural income differential. ${ }^{45}$ This is one of the reasons why the World Bank has advocated the removal of residual controls on migration in the 1990s. If the floating population were to be included in the urban survey, the overall effect would therefore be ambiguous. On the one hand, it would raise the intra-urban gini coefficient and therefore increases the overall gini coefficient. On the other hand, it would narrow the income gap between urban and rural China, thereby reducing the

40. John Knight, Song Lina and Jia Huaibin, "Chinese rural migrants in urban enterprises," in Cook and Maurer-Fazio, Workers' State, p. 84. A larger study of 7,973 households drawn from across China found that "outsiders" earned only $54 \%$ of the "insider" wage in Beijing in 1995. However, the ratio was much higher in Guangdong $(85 \%)$ and in two provinces (Shandong and Jiangsu) outsiders earned more than insiders; see Li Shi, "Zhongguo nongcun laodongli liudong yu shouru zengzhang he fenpei" ("The migration of rural labour in China and its income growth and distribution"), Zhongguo shehui kexue (Social Sciences in China), No. 2 (March 1999), p. 20. These figures may be misleading in that they probably include permanent migrants as well as floaters.

41. SCMP, 17 April 1998.

42. SCMP, 15 October 1997.

43. The SSB embarked upon a programme of collaboration with the World Bank in 1999-2000 to widen the urban sample frame to include migrants.

44. The way this fee system operated in Beijing in the mid-1990s is discussed in Michael Dutton, Streetlife China (Cambridge: Cambridge University Press, 1999).

45. Technically, this conclusion rests upon the assumptions that the urban wage exceeds subsistence and that the labour supply curve is upward-sloping. Otherwise, the post-migration wage will not change. Both assumptions seem plausible for urban China, although lay-offs from state-owned enterprises made the labour supply curve more flat during the late 1990s. 
Table 3: Subsidies Paid to Urban Residents, 1990 and 1995 (yuan per capita, current prices)

\begin{tabular}{lrr}
\hline & 1990 & 1995 \\
\hline Income & 1,629 & 4,612 \\
Subsidies & 1,280 & 3,304 \\
$\quad$ Of which: & 730 & 1,960 \\
$\quad$ Housing & 101 & 595 \\
Old age insurance & 119 & 306 \\
$\quad$ Health & 129 & 252 \\
$\quad$ Education & 3 & 14 \\
$\quad$ Transport & 121 & 59 \\
$\quad$ Prices & 45 & 87 \\
Subsidies in kind (wupin) & 18 & 31 \\
$\quad$ Other subsidies & & \\
\hline
\end{tabular}

\footnotetext{
Source:

Wang and Lu, Research, pp. 203-204. The 1995 data are also re-produced in World Bank, Sharing, p. 19.
}

overall gini coefficient. ${ }^{46}$ Migration is therefore no simple panacea for the problem of income inequality.

A second reason why the revised surveys of income inequality may over-state inequality concerns the subsidies paid to urban workers. The SSB urban income surveys exclude almost all subsidies except pensions (which are included under transfer income) ${ }^{47}$ This transfer income was valued at 740 yuan in the SSB survey for 1995. Khan and Riskin expand the subsidy category further to include housing and other net subsidies, which they value at an additional 626 yuan, thus bringing the revised per capita subsidy total to 1,366 yuan.$^{48}$ Even so, this revised accounting still vastly under-states the true value of urban subsidies. According to a more detailed SSB calculation, in addition to an income of 1,629 yuan per capita, each urban citizen received a fuli shouru (subsidy income) of 1,280 yuan in 1990. The corresponding figures for 1995 were 4,612 and 3,304 yuan respectively, and this latter figure is clearly far greater than the Khan and Riskin estimate of subsidy income. The scale of the subsidies paid to the urban population is outlined in Table 3.

The point about subsidies is not merely that they are larger than suggested by Khan and Riskin, but that they serve to make the urban

46. A recent World Bank study (Sharing, p. 53) argues that the net effect is positive: "Migration alleviates the pronounced inequality between poor rural people and wealthy urbanites and helps redistribute rural incomes because migrants send significant portions of their earnings back to their families. Although migration may be increasing inequality among urban residents, national inequality would likely be more severe in the absence of migration."

47. See SSB, ZGTJNJ 1995, p. 262. The category zhuanyixing shouru is translated as "transfer income" in ZGTJNJ 1999 but as "pensions, subsidies, donations and other" in the 1995 edition.

48. Khan and Riskin, "Income and inequality," p. 229. 
distribution of income much more equal. ${ }^{49}$ This is because the poorest urban households receive disproportionately more in subsidies than do the richest households. In 1995, for example, the per capita subsidy received by the poorest 10 per cent of households was 2,076 yuan, which was 17 per cent greater than their income. By contrast, the subsidies received by the richest 10 per cent of households amounted to much more in cash terms $(3,882$ yuan $)$ but to only 38 per cent of their income. The effect, therefore, of including the full value of subsidies in estimating the urban income distribution is greatly to reduce urban inequality. According to one set of estimates, the 1995 urban gini of 0.28 (the SSB estimate) falls to only 0.21 once subsidies are included. ${ }^{50}$ This, of course, does not mean that urban inequality was unchanging in the 1990s. The post-subsidy urban gini shows a rise from 0.16 in 1990 to 0.21 in 1995; this increase is actually greater than the increase in the pre-subsidy urban gini. The reason is that subsidies as a percentage of income became less generous over the course of the 1990s (falling from 78 per cent of income in 1990 to 72 per cent in 1995) and in this process the subsidies paid to the poor fell more quickly than those paid to the rich. ${ }^{51}$ For example, the subsidy income received by the bottom 10 per cent increased by 109 per cent but that of the richest 10 per cent rose by 141 per cent. Nevertheless with the bottom decile receiving subsidies valued at 117 per cent of their income and the top decile receiving subsidies of only 38 per cent, the net impact of subsidies were still clearly re-distributive.

A final problem arises because the survey-derived personal income data are at current prices. In principle, aggregation problems arise here because of regional price differences; an income of 1,000 yuan might translate into significantly less purchasing power in Beijing than in Guizhou. This posed few difficulties at the beginning of the transition period when most prices were set by the state in such a way as to minimize regional differences. In 1952, before the introduction of the state-controlled system of grain procurement, large inter-provincial price differences were the norm. For example, the price paid for wheat in Yunnan was 50 per cent below the national average. By 1965, however, the wheat prices had been equalized and in 1978 the Yunnan price was actually slightly higher. ${ }^{52}$ The same pattern of growing equalization is clear for other agricultural commodities and for other provinces. By the mid-1990s, however, significant regional price differences had reemerged. This is apparent from the different urban poverty lines introduced in China's cities during the 1990s. Those introduced in the summer of 1996, for instance, drew the poverty line at 120 yuan per month in

49. The new system of personal income taxation introduced in January 1994 has the same effect because of its progressive nature; for example, the first 800 yuan of monthly income is exempt from tax and the marginal tax rate on incomes over 50,000 yuan per month is $100 \%$. It is not yet clear, however, how much evasion takes place.

50. Wang and Lu, Research, p. 179.

51. The ratio of subsidies to income fell from 138 to $117 \%$ for the poorest $10 \%$ of households between 1990 and 1995, and from 50 to $38 \%$ for the richest $10 \%$ of households (ibid. p. 205).

52. Zhonggong Yunnan sheng wei zhengce yanjiushi (Policy Research Unit of the Yunnan Party Committee), Yunnan sheng qing (Conditions in Yunnan), (Kunming: Yunnan renmin chubanshe, 1986), p. 1026. 
Chongqing, Shijiazhuang, Hefei and Jinan but at 150 yuan in Ningbo and 170 yuan in Beijing. In Shanghai, the poverty line was set at 185 yuan as early as 1993, and was 200 yuan in Guangzhou in mid-1995. ${ }^{53}$

However, it is not easy to judge the impact of these price differences on the distribution of income. One study, using provincial-level cost of living indices to re-value income, found that inequality as measured by the Theil coefficient fell from 0.32 to 0.28 in 1990 after price adjustment. ${ }^{54}$ But there can be no easy presumption that inequality in general would be lower after these sorts of adjustments. For one thing, a great deal of data are needed because of large intra-provincial variations in the cost of living. For example, current price gross agricultural output (GVAO) in Jinniu, a suburb of Chengdu, was 2.14 times its constant (1990) price valuation in 1996 but the ratio in Zhaojue (one of the poorest counties in Sichuan) was only 1.34 to 1 . Secondly, there was no clear relationship between high prices and high levels of nominal income. To give an illustration, the gini coefficient for nominal GDP per head in Sichuan's counties and cities in 1996 was 0.31 . But if one adjusts GDP in every county for varying ratios of current to constant price GVAO in other words, if it is assumed that every county had the same inflation rate between 1990 and 1996 - the gini coefficient is virtually unchanged at $0.30 .^{55}$ This is of course a very ad hoc adjustment; ideally one would use retail price data for each county. But it does illustrate the general point that high nominal GDP and/or proximity to the provincial capital did not of itself guarantee a high inflation rate. Moreover, the use of official poverty lines does not really help. This is because the setting of the threshold was influenced by the generosity of local government as well as by its assessment of "objective" need. In short, it is virtually impossible to determine the impact of regional price differences on the distribution of income. For that very reason, one should be cautious about making definitive pronouncements on the trajectory of inequality after 1978.

\section{Conclusion}

There is surely little doubt that income inequality has spiralled in China since 1978. The official SSB data show an increase in the gini coefficient from about 0.3 to around 0.4 between 1978 and 1996. The adjustments made by Khan and Riskin point towards a steeper rate of increase, the gini reaching a level of nearer to 0.45 by the mid-1990s. And there is an abundance of anecdotal evidence pointing to the same conclusion. It is hard to conceive of any adjustments to the household income surveys which would reverse this conclusion.

For policy purposes, however, it is necessary to know why inequality

53. Wang and Lu, Research, p. 226.

54. Ravallion and Chen 1997, cited in World Bank, Sharing, p. 18.

55. The Sichuan data come from Sichuan tongjiju (Sichuan Statistical Bureau), Sichuan tongji nianjian 1997 (Sichuan Statistical Yearbook), (Beijing: Zhongguo tongji chubanshe, 1997). 
rose. ${ }^{56}$ If the major cause is spatial, the policy solution might be to remove residual restrictions on labour mobility. Alternatively, the Chinese state could seek to re-distribute income, using a combination of taxes and subsidies, from rich areas (mainly the cities and rural eastern China) to the hinterland. But if inequality has risen because of growing differentials within the cities and the countryside, an altogether different raft of policies would have to be adopted; these might centre on the development of a much more progressive system of income taxation.

Unfortunately the existing survey data, even as adjusted in recent years by Chinese and Western researchers, are simply not good enough to show why inequality has risen. Inequality can be thought of as being determined by three factors: inequality within rural areas, inequality within urban areas, and the urban-rural income gap. In the rural sector, the exclusion of many illiterate households at the bottom end of the income scale, and private sector entrepreneurs at the top, means that even the revised rural gini coefficients understate true rural inequality. Assessing the true degree of urban inequality is still more difficult. This is mainly because even the revised data exclude the majority of private entrepreneurs, ${ }^{57}$ the floating population, illiterate households and a significant proportion of urban subsidies; they also take no account of regional price differences in the cost of living. Of these weaknesses, the exclusion of the first three leads to an understatement of true urban inequality. However, the exclusion of many subsidies, the last category, leads to an overstatement. Furthermore, none of these categories has remained time-invariant: the impact of the various biases has changed over time as the number of illiterates has fallen and the number of private sector entrepreneurs has increased. The net impact can only be guessed.

As for the urban-rural income differential (which, along with the sectoral coefficients, determines the overall gini coefficient), it is again hard to be certain of its size: all the continuing flaws in even the revised assessments of income in urban and rural China necessarily show up in estimates of the urban-rural gap. Moreover, the biases run in both directions, especially for urban per capita income. If the floating population living in urban areas but not covered by the urban surveys were included, the urban-rural gap would be reduced because their inclusion would depress urban wages and raise rural incomes (via remittances). But against this, if the large subsidies paid to urban residents were accurately measured, the absolute urban-rural gap would be even wider. The size of the gap has probably narrowed since 1978 - if anything, subsidies as a percentage of urban income have fallen and migration has depressed

56. Although it is fair to say that there was a general perception in China by the mid-1990s that spatial inequality had increased beyond acceptable bounds. It was this perception that influenced policy formulation, in particular the introduction of a range of programmes (such as the creation of a Western Region Development Office) designed to raise incomes in rural western China, as much as any "objective" reality. I am indebted to a referee for this observation.

57. This problem is much greater in the urban than in the rural sector simply because the vast majority of high income private entrepreneurs live in urban areas. 
urban wages - but it is impossible to tell by how much from the data generated by the urban and rural household surveys.

In sum, one needs to be aware of the fragile foundation on which any pronouncements about the reasons for the surge in Chinese income inequality are based. To rely too heavily for policy purposes on the findings of decomposition analysis in these circumstances appears ill-advised. ${ }^{58}$ Better data are needed first.

58. A case in point is the tendency of Khan and others to use their revisions to the SSB data for 1988 and 1995 far too uncritically in order to delineate and explain the persistence of rural poverty. See Azizur Rahman Khan, Poverty in China in the Period of Globalization (Geneva: ILO discussion paper No. 22, 1998), and UNDP/ILO, "Policies for poverty reduction in China" (unpublished UNDP ms., February 2000). 